\title{
Reduced Surface Runoff Losses of Metolachlor in Narrow-Row Compared to Wide-Row Soybean
}

\author{
L. Jason Krutz, ${ }^{*}$ Clifford H. Koger III, Martin A. Locke, and Robert W. Steinriede, Jr. USDA-ARS
}

Cultural management practices that reduce the off-site transport of herbicides applied to row crops are needed to protect surface water quality. A soybean [Glycine $\max$ (L.) Merr.] field study was conducted near Stoneville, MS on Sharkey clay to evaluate row spacing $(50 \mathrm{~cm}$ vs. $100 \mathrm{~cm})$ effects on metolachlor [2-chloro- $N$-(2-ethyl-6-methylphenyl)- $N$ (methoxy-1-methylethyl) acetamide] transport. One day after the foliar application of metolachlor to $2.03 \mathrm{~m}$ wide by 2.43 $\mathrm{m}$ long plots, $60 \mathrm{~mm} \mathrm{~h}^{-1}$ of simulated rainfall was applied until $25 \mathrm{~min}$ of runoff was generated per plot. The calculated mass of metolachlor intercepted by the soybean foliage was greater in narrow-row than wide-row soybean, $0.39 \mathrm{~kg} \mathrm{ha}^{-1}$ vs. $0.23 \mathrm{~kg} \mathrm{ha}^{-1}$, respectively. Field and laboratory studies indicated that less than $2 \%$ of the metolachlor intercepted by the soybean foliage was available for foliar wash-off $1 \mathrm{~d}$ after application. Antecedent soil water content at the start of the simulations was lower in narrow-row soybean. In turn, there was a 1.7 -fold greater time to runoff on narrow-row plots. The greater time to runoff likely contributed to lower metolachlor concentration in runoff from narrow-row plots. Cumulative metolachlor losses were significantly greater in wide-row than narrow-row soybean, $3.7 \%$ vs. $2.2 \%$, respectively. Findings indicate that narrow-row planting systems may reduce metolachlor runoff following a post-emergence application.

Copyright $\odot 2007$ by the American Society of Agronomy, Crop Science Society of America, and Soil Science Society of America. All rights reserved. No part of this periodical may be reproduced or transmitted in any form or by any means, electronic or mechanical, including photocopying, recording, or any information storage and retrieval system, without permission in writing from the publisher.

Published in J. Environ. Qual. 36:1331-1337 (2007). doi:10.2134/jeq2006.0548

Received 19 Dec. 2006.

*Corresponding author (Jason.krutz@ars.usda.gov). ( ) ASA, CSSA, SSSA

677 S. Segoe Rd., Madison, WI 53711 USA
$\mathrm{M}$ ETOLACHLOR is a non-polar herbicide used in a variety of row crops including corn (Zea mays L.), cotton (Gossypium hirsutum L.), and soybean [Glycine max (L.) Merr.]. Metolachlor and associated metabolites are frequently detected in lakes, streams, and reservoirs throughout the United States, particularly in regions of intense soybean and corn production (Scribner et al., 2000; Lerch and Blanchard, 2003; Kalkhoff et al., 2003; Rebich et al., 2004; Hackett et al., 2005; Zablotowicz et al., 2006). Runoff from row crops where metolachlor is a component of weed control programs is the primary mechanism for its transport to surface water bodies (Scribner et al., 2000; Lerch and Blanchard, 2003; Hackett et al., 2005). Cultural management practices that limit the transport of metolachlor from the site of application are needed to protect surface water quality.

Planting soybean in narrow rows, i.e., less than $76 \mathrm{~cm}$, is a cultural management practice that alters specific parameters in the cropping system whereby transport of non-polar herbicides applied to the crop canopy may be reduced relative to a cropping system with wider row spacing. Altered parameters in narrow-row systems that may reduce runoff losses of foliar-applied, non-polar compounds include (i) greater canopy coverage, foliar interception, and foliar absorption, (ii) greater water use, lower antecedent soil moisture, and delayed time to runoff, and (iii) reduced soil erosion (Shelton et al., 1986; Truman and Williams, 2001).

Canopy coverage in narrow-row soybean is greater than that of wide-row soybean at the latest growth stage that metolachlor can be applied over the top of the canopy, i.e., the four-leaf growth stage (personal observation). Since the interception of foliar-applied pesticides is proportional to the canopy coverage at the time of application (Beverlein and Donigian, 1979), more pesticide is likely to be intercepted by the canopy in narrow-row systems than wide-row systems. When lipophilic and/or non-polar pesticides are intercepted by foliage, the compounds penetrate waxes at the leaf surface and become difficult to dislodge by rainfall (McDowell et al., 1985; Leonard, 1990). Thus, due to greater canopy coverage and foliar interception in narrow-row systems, there is potential to limit the mass of non-polar, foliar-applied pesticides that reaches the mixing zone, i.e., the surface 2 to $3 \mathrm{~mm}$ of soil where pesticides are entrained in runoff through a mixing-extraction process (Ahuja, 1986; Leonard, 1990). Since the concentration of a pesticide in surface runoff is strongly correlated to the pesticide mass in the mixing zone (Leonard et al., 1979), runoff losses of foliar-applied, non-polar pesticides may be reduced in narrow-row systems.

L.J. Krutz, USDA-ARS, Southern Weed Science Research Unit, P.O. Box 350, Stoneville, MS 38776; C.H. Koger III, USDA-ARS, Crop Genetics and Production Research Unit, P.O. Box 350, Stoneville, MS 38776; M.A. Locke and R.W. Steinriede, Jr., USDA-ARS, National Sedimentation Lab., P.O. Box 1157, Oxford, MS 38655.

Abbreviations: MDL, method detection limit. 
A more even distribution of plant roots in the soil profile is achieved in narrow-row systems than wide-row systems, indicating potential for differential use of soil water between cultural management practices. Although differential use of soil water between narrow- and wide-row systems is a point of contention in the literature, greater use of soil water has been reported for some narrow-row systems (Sharrat and McWilliams, 2005; Dalley et al., 2006). Thus, there is potential for the antecedent soil moisture content to be lower in narrow-row systems. Low antecedent soil moisture at inception of rainfall increases infiltration, delays time to runoff, and reduces the concentration of herbicide in runoff due to greater leaching of the pesticide below the mixing zone (Leonard, 1990). Consequently, the cumulative loss of herbicides in runoff is positively correlated with antecedent soil moisture content (Zhang et al., 1997; Smith et al., 2002).

Cultural management practices that decrease soil erosion will reduce the potential for off-site transport of pesticides that are strongly sorbed to soil colloids. Relative to wide-row soybean, Shelton et al. (1986) reported that soil erosion and erosion rates were reduced by 50 and 37\%, respectively, for narrow-row soybean when averaged over tillage systems, i.e., double disk, tillage-plant, strip rotary-tillage, and non-tillage. Similar results were reported for twin-row peanut (Arachis hypogaea L.) compared to single-row peanut (Truman and Williams, 2001).

Despite the potential to reduce herbicide transport using alternative row spacings, no study has compared the transport of herbicides between narrow- and wide-row systems. The objective of this experiment was to compare effects of row spacing on foliar interception, foliar absorption, foliar rainfall wash-off, and runoff losses of metolachlor applied to the foliage of soybean at the four-leaf growth stage.

\section{Materials and Methods}

\section{Site Description}

Field studies were conducted in 2006 on the Delta Branch Experiment Station near Stoneville, MS $\left(33^{\circ} 26^{\prime} \mathrm{N}\right)$ on a Sharkey Clay (very-fine, smectitic, thermic chromic Epiaquert) consisting of $3 \%$ sand, $32 \%$ silt, $66 \%$ clay, $3.0 \%$ organic matter, $1 \%$ slope, and a $\mathrm{pH}$ of 6.4 . Plots were disk-harrowed, spring-tooth cultivated, and bedded in the fall of 2005. An Orthman model 504-30B bed shaper (Orthman Mfg. Inc., Lexington, NE) with two lister bottom busters centered directly behind the tractor tires was used to construct beds that were $2.03 \mathrm{~m}$ wide and approximately 0.20 $\mathrm{m}$ in height. Two weeks before planting soybeans, glyphosate [ $N$-(phosphonomethyl)glycine] was applied at $1.12 \mathrm{~kg} \mathrm{ae} \mathrm{ha}^{-1}$ in $47 \mathrm{~L} \mathrm{ha}^{-1}$ water to kill existing weed vegetation.

Soybean, Pioneer 94M80 Roundup Ready (Pioneer HiBreed International Inc., Johnston, IA), treated with mefanoxam $[(R)$-2-\{2,6-dimethylphenyl)-methoxyacetylamino\}-propionic acid methyl ester] and fludioxonil [4-(2,2-difluoro-1,3-benzodioxol-4-yl)-1 $H$-pyrrole-3-carbonitrile] at 0.038 and $0.025 \mathrm{~g}$ a.i. $\mathrm{kg}^{-1}$ seed, respectively, were planted in either a narrow-row or wide-row configuration. The wide-row system consisted of planting two rows spaced $100 \mathrm{~cm}$ apart centered on a $2.0 \mathrm{~m}$ wide bed, and the narrow-row system consisted of four rows spaced 50 $\mathrm{cm}$ apart on a $2.0 \mathrm{~m}$ wide bed. The same seeding rate, 323708 seed $\mathrm{ha}^{-1}$, was planted regardless of row configuration resulting in the same number of plants per plot. Metolachlor formulated as Sequence (Syngenta Crop Protection, Greensboro, NC) was applied at $1.26 \mathrm{~kg}$ a.i. ha $^{-1}$ with 8003 flat fan spray tips (Spraying Systems Co., Wheaton, IL) from a height of $48 \mathrm{~cm}$ above soybean in the four-leaf growth stage with a compressed air tractormounted sprayer delivering $140 \mathrm{~L} \mathrm{ha}^{-1}$ at $206 \mathrm{KPa}$. Metolachlor application rate was verified by arranging four $7 \mathrm{~cm}$ diam. filter paper spray targets (Whatman no.2, Whatman Inc., Clifton, NJ) on the soil surface adjacent to each plot.

\section{Rainfall Simulations}

Plots, $2.03 \mathrm{~m}$ wide by $2.43 \mathrm{~m}$ long, were centered over the beds and delineated with aluminum frames pressed approximately 10 $\mathrm{cm}$ into the soil surface. The $2.43-\mathrm{m}$ side was positioned parallel to the bed and in the center of each row, while the 2.03 - $\mathrm{m}$ side was perpendicular to the bed. Antecedent soil water content was determined gravimetrically on surface soil samples collected adjacent to the plot at three depths. Canopy coverage at the time of herbicide application was determined using digital imagery (Purcell, 2000). As described elsewhere, an oscillating nozzle rainfall simulator was used to deliver a nominal rainfall intensity of $60 \mathrm{~mm} \mathrm{~h}^{-1}$ (Wauchope, 1987a, 1987b). Rainfall simulations were initiated $1 \mathrm{~d}$ after metolachlor application and continued until $25 \mathrm{~min}$ of runoff was generated per plot. All runoff generated during the simulation was captured in a holding tank positioned on the down-slope end of the plot. Runoff rate was determined by manually recording the water height in the holding tank at 60-s intervals. Runoff samples were collected for herbicide and sediment analysis at $0,10,15$, 20, and $25 \mathrm{~min}$ in 1-L glass bottles. Additionally, at the end of the simulation, a composite sample was collected in a 1-L glass jar from the holding tank that contained all runoff generated during the simulation. All glass bottles were sealed with Teflon-lined screw caps, placed on ice, and transferred to the laboratory refrigerator within $1 \mathrm{~h}$ of completing the simulation.

\section{Field Foliar Wash-off}

Before applying simulated rainfall, above-ground portions of two plants were clipped at the soil surface from an area adjacent to the runoff plot, and above-ground portions of two plants were clipped at the soil surface in the rainfall plot after the simulation. Foliage from each plant was rinsed individually for $5 \mathrm{~min}$ in 1-L glass jars containing $250 \mathrm{~mL}$ of water, and the water was analyzed for metolachlor.

\section{Laboratory Foliar Wash-off, Absorption, and Translocation}

Soybean seed, Pioneer 94M80 Roundup Ready (Pioneer HiBreed International Inc., Johnston, IA), was planted in 11-cm diam. plastic pots containing a $1: 1 \mathrm{v} / \mathrm{v}$ ratio of potting mix (Jiffy mix, Jiffy Products of America Inc., Batavia, IL) and Bosket sandy loam (fine-loamy, mixed thermic Mollic Hapludalfs). Upon emergence, plants were thinned to one per pot, watered daily, and maintained in a greenhouse at $30 / 20^{\circ} \mathrm{C}$ day/night temperature with a 14 -h photoperiod. When the fourth soybean leaf was fully 
expanded, a 5- $\mu \mathrm{L}$ volume of formulated metolachlor product [Sequence (Syngenta Crop Protection, Greensboro, NC) containing $0.46 \mathrm{kBq}$ of ${ }^{14} \mathrm{C}$-metolachlor $\left(3.05 \times 10^{5} \mathrm{kBq} \mathrm{mmol}^{-1}\right.$ specific activity; $96 \%$ radio-chemical purity)] was deposited on the adaxial surface of the terminal leaflet of the fourth fully expanded leaf as five $1-\mu \mathrm{L}$ droplets. Plants were harvested at 1, 2, 4, 8, and $24 \mathrm{~h}$ after treatment. Plants and roots were divided into treated terminal leaflet, remaining leaf and petiole, foliage above and below treated leaf, and roots. To remove non-absorbed herbicide, the treated terminal leaflet was rinsed by gently shaking for $15 \mathrm{~s}$ in $15 \mathrm{~mL}$ of distilled water adjusted to $\mathrm{pH} 5.7$ with $85 \%$ phosphoric acid. Two $1-\mathrm{mL}$ aliquots of the leaflet rinse were added to $15 \mathrm{~mL}$ of scintillation fluid (Ecolume, ICN Biomedicals, Irvine, CA), and radioactivity was quantified by liquid scintillation spectroscopy (LSS) (TriCarb 2500, Packard Instruments Co., Downers Grove, IL). Plant sections were wrapped in tissue paper (Kimberly-Clark, Roswell, GA), placed in glass scintillation vials, and oven-dried at $40^{\circ} \mathrm{C}$ for $48 \mathrm{~h}$. Oven-dried plant samples were combusted with a biological sample oxidizer (Packard oxidizer 306, Packard Instrument Co., Meriden, CT), and sample radioactivity was quantified by LSS. The amount of ${ }^{14} \mathrm{C}$ present in leaflet washes and plant sections was considered total ${ }^{14} \mathrm{C}$ recovered. The amount of ${ }^{14} \mathrm{C}$ present in the leaflet wash was considered available for foliar wash-off and was expressed as the percentage of ${ }^{14} \mathrm{C}$ recovered. The sum of the radioactivity present in all plant parts was considered to be absorbed and was expressed as the percentage of ${ }^{14} \mathrm{C}$ recovered, and the sum of the radioactivity present in all plant parts excluding the treated terminal leaflet was considered translocated and was expressed as the percentage of ${ }^{14} \mathrm{C}$ recovered.

\section{Sample Preparation and Analysis}

Total sediment in runoff was determined by transferring a 200-mL aliquot of well-shaken runoff sample into a tared beaker and recording the weight of the residue after oven-drying. Spray targets were extracted $1 \mathrm{~h}$ after collecting by shaking $24 \mathrm{~h}$ with 25 $\mathrm{mL}$ methanol, and a 1-mL aliquot was removed for analysis. Runoff samples were thoroughly shaken, and $10-\mathrm{mL}$ subsamples were removed and fortified with terbuthazine at $5 \mathrm{ug} \mathrm{mL} \mathrm{m}^{-1}$. Subsamples then were extracted using a $3-\mathrm{mL} \mathrm{C}_{18}$ solid phase extraction column (Bakerbond, JT Baker Phillipsburg, PA) preconditioned with $4 \mathrm{~mL}$ methanol followed by $4 \mathrm{~mL}$ distilled water. The column was eluted with $2 \mathrm{~mL}$ methanol under negative pressure, and the extract was dried to $1 \mathrm{~mL}$ under a stream of nitrogen. Components of all extracts were identified and quantified using a Waters 2695 high performance liquid chromatography (HPLC) separations module equipped with a Waters 996 photodiode array detector (Waters Corp., Milford, MA). The HPLC was fitted with a 2.1mm-diam. by 150 -mm-length Waters Symmetry $\mathrm{C}_{18}$ column (Waters Corp., Milford, MA). The mobile phase solvents were HPLC grade and consisted of acetonitrile and water (55:45 v/v). Mobile phase flow rate was constant at $1.0 \mathrm{~mL} \mathrm{~min}^{-1}$. The method detection limit (MDL), based on the low concentration standard $\left(0.1 \mu \mathrm{g} \mathrm{mL}^{-1}\right.$ in each calibration), was $10.0 \mu \mathrm{g} \mathrm{\textrm {L } ^ { - 1 }}$.

\section{Quality Control}

Recovery of metolachlor from fortified filter paper used for spray targets was $93 \pm 1 \%(n=8)$. Field application rates were adjusted based on these recovery values. Metolachlor was below the MDL in all field blank water samples collected from the simulator holding tank before each rainfall event, and the concentration of metolachlor was below the MDL in all laboratory blanks. Matrix fortified samples were prepared by adding $0.4 \mathrm{~mL}$ of $50 \mu \mathrm{g} \mathrm{mL}^{-1}$ metolachlor solution to $10 \mathrm{~mL}$ of field blank sample. The average recovery of metolachlor from these samples was $110 \pm 12 \%$ $(n=12)$. Field runoff samples were not adjusted for recovery.

\section{Data Calculations}

Herbicide and sediment concentrations were multiplied by the volume of runoff represented by the samples taken for analysis, and the results were summed to give total loads. Estimates for cumulative mass loss were obtained by multiplying the average concentration for each time step by the corresponding runoff volume. Average concentrations in the portion of the runoff that were not analyzed were estimated by linear interpolation between adjacent data points on chemographs (Potter et al., 2003). The mass of metolachlor intercepted by the soybean canopy was calculated by multiplying herbicide mass applied $\left(\mathrm{kg} \mathrm{ha}^{-1}\right)$ by the soybean canopy coverage at the time of application (Beverlein and Donigian, 1979). Herbicide mass available for wash-off $1 \mathrm{~d}$ after herbicide application was calculated by multiplying water-extractable metolachlor $\left(\mathrm{g} \mathrm{plant}^{-1}\right.$ ) by the plant density (plants ha ${ }^{-1}$ ) (Wauchope et al., 2004). The mass of metolachlor remaining on the crop canopy following rainfall simulation was calculated by multiplying water-extractable herbicide following the simulated rainfall event $\left(\mathrm{g} \mathrm{plant}^{-1}\right.$ ) by the plant density (plants ha ${ }^{-1}$ ) (Wauchope et al., 2004). Herbicide wash-off (\%) was determined by the following equation: Wash-off $=\left[\left(\right.\right.$ Pre-rainfall $\left(\mathrm{g} \mathrm{ha}^{-1}\right)-$ Post-rainfall $\left.\left(\mathrm{g} \mathrm{ha}^{-1}\right)\right) /$ Pre-rainfall $\left.\left(\mathrm{g} \mathrm{ha}^{-1}\right)\right] \times 100$ (Wauchope et al., 2004).

\section{Statistical Analysis}

Field and laboratory experiments were analyzed in SAS GLM (SAS Institute, 2004) as a randomized complete block with three replications of each treatment. Treatments for the field study included wide- and narrow-row spacing, and treatments for the laboratory study included time $(1,2,4,8$, and $24 \mathrm{~h}$ after metolachlor application). Experiments were repeated in time and space, and after statistical analysis indicated no difference between data sets, data were pooled across experiments. Regression analysis was used to determine relationships between independent and dependent variables (SAS Institute, 2004).

\section{Results and Discussion}

\section{Hydrology}

Antecedent soil moisture at all three depth intervals was lower in narrow-row soybean (Table 1). Crop row spacing influences canopy architecture and, in some instances, utilization of soil water (Sharrat and McWilliams, 2005). Greater soil water use in narrow-row systems compared to wide-row systems has been reported for corn (Sharrat and McWilliams, 2005; Dalley et al., 2006). Our soil moisture data indicate greater water use in narrow-row vs. wide-row soybean, likely 
Table 1. Metolachlor application rate, antecedent soil moisture content, canopy coverage, and rainfall applied to narrow- and wide-row soybeans.

\begin{tabular}{|c|c|c|c|c|c|c|}
\hline \multirow[b]{2}{*}{ Treatment } & \multirow[b]{2}{*}{$\begin{array}{c}\text { Mass } \\
\text { applied } \dagger\end{array}$} & \multicolumn{3}{|c|}{ Gravimetric soil moisture content } & \multirow[b]{2}{*}{$\begin{array}{l}\text { Canopy } \\
\text { coverage }\end{array}$} & \multirow[b]{2}{*}{$\begin{array}{c}\text { Rain } \\
\text { applied§ }\end{array}$} \\
\hline & & 0 to $7 \mathrm{~cm}$ & 7 to $15 \mathrm{~cm}$ & 15 to $25 \mathrm{~cm}$ & & \\
\hline & $\mathrm{kg} \mathrm{ha}^{-1}$ & & $-\mathrm{g} \mathrm{g}^{-1}$ & & $\%$ & $\mathrm{~mm}$ \\
\hline Narrow row & $1.29(0.1) \#$ & $0.25(0.04)$ & $0.38(0.02)$ & $0.41(0.02)$ & $31(7)$ & $47.6(4.4)$ \\
\hline Wide row & $1.3(0.1)$ & $0.36(0.03)$ & $0.44(0.04)$ & $0.45(0.02)$ & $18(3)$ & $38.4(4.7)$ \\
\hline$P$ value & 0.7702 & 0.0007 & 0.0272 & 0.0006 & 0.0030 & 0.0020 \\
\hline
\end{tabular}

† Nominal metolachlor application rate $=1.26 \mathrm{~kg} \mathrm{ha}^{-1}$.

‡ Canopy coverage determined using digital imagery (Purcell 2000).

$\S$ Nominal rainfall application rate $=60.0 \mathrm{~mm} \mathrm{~h}^{-1}$.

I Values are the mean of six replicates.

\# Value contained in bracket indicate one standard deviation.

due to a more even distribution of plant roots in the former.

Greater water use in narrow-row soybean altered the hydrology relative to the wide-row system (Table 2; Fig. 1). Time to runoff was delayed almost twofold in the narrow-row system allowing approximately $9 \mathrm{~mm}$ more water to infiltrate before inception of runoff (Table 2). However, during the 25 min runoff event, there was no difference in the runoff rate or total runoff loss between cropping systems (Fig. 2; Table 2). This indicates that greater water use in narrow-row soybean primarily altered the system's hydrology by decreasing the soil moisture content, increasing infiltration and, ultimately, increases the time to runoff. Shelton et al. (1986) reported that the time to runoff was greater for tillage systems in narrow-row soybean than in widerow soybean; moreover, in the narrow-row system, total runoff and runoff rate were reduced by 36 and $17 \%$, respectively. These observations were attributed to a more even distribution of plant roots in the narrow-row system that provided a more uniform series of pathways for infiltration. Similarly, Truman and Willams (2001) reported that total runoff from twin-row peanut was three times less that that from single-row peanut.

\section{Sediment Transport}

During the 25 min runoff event, average sediment concentration and cumulative sediment loss were independent of row spacing (Fig. 3, Table 2). However, due to a twofold delay in the time to runoff in the narrow-row system, there was a 10-min interval when only the wide-row system was generating runoff and transporting sediment. During this time interval, more sediment was transported in the wide-row system than the narrow-row system.

Table 2. Hydrology, chemical transport, and sediment transport in narrow- and wide-row soybeans.

\begin{tabular}{|c|c|c|c|c|c|}
\hline \multirow[b]{2}{*}{ Treatment } & \multicolumn{2}{|c|}{ Hydrology } & \multicolumn{2}{|c|}{ Chemical transport } & \multirow{2}{*}{$\begin{array}{c}\begin{array}{c}\text { Sediment } \\
\text { transport }\end{array} \\
\begin{array}{c}\text { Total mass } \\
\text { loss }\end{array}\end{array}$} \\
\hline & $\begin{array}{l}\text { Time to } \\
\text { runoff }\end{array}$ & $\begin{array}{l}\text { Total runoff } \\
\text { loss }\end{array}$ & $\begin{array}{c}\text { Total mass } \\
\text { loss }\end{array}$ & $\begin{array}{c}\text { Fraction of } \\
\text { applied }\end{array}$ & \\
\hline & $\min$ & $\mathrm{mm}$ & $\mathrm{g} \mathrm{ha}^{-1}$ & $\%$ & $\mathrm{~g} \mathrm{~m}^{-2}$ \\
\hline Narrow row & $22.6+(4.7) \neq$ & $7.2(0.8)$ & $22.6(13.2)$ & $2.2(1.1)$ & $113.2(71.1)$ \\
\hline Wide row & $13.4(4.4)$ & $7.0(1.7)$ & $47.5(22.9)$ & $3.7(1.7)$ & $116.1(32.3)$ \\
\hline$P$ value & 0.0020 & 0.6688 & 0.0180 & 0.0165 & 0.9067 \\
\hline
\end{tabular}

† Value is the mean of six replicates.

‡ Value in parenthesis indicates one standard deviation.
Consequently, cumulative sediment loss was statistically lower in narrow-row soybean than wide-row soybean from 15 to $45 \mathrm{~min}$ after application of simulated rainfall. Thus, data indicate the potential for narrow-row soybean to reduce sediment transport relative to wide-row systems inasmuch as time to runoff is delayed.

\section{Spray Rate Validation}

The recovery of metolachlor from spray targets indicated a high level of precision and accuracy across plots and experiments (Table 1). Relative to the nominal application rate of $1.26 \mathrm{~kg} \mathrm{ha}^{-1}$, the measured application rate in narrow-row soybean was $99 \pm 7 \%$ compared to $100 \pm 5 \%$ for wide-row soybean. These measured deposit amounts were used to calculate foliar interception at the time of application and runoff losses as a fraction of metolachlor applied.

\section{Field Foliar Wash-off}

Soybean canopy coverage and the mass of metolachlor intercepted by the soybean canopy at the time of herbicide application was 1.7-fold greater in narrow-row soybean (Table 1, Table 3). The mass of metolachlor recovered from the soybean foliage pre- and post-rainfall was independent of row spacing, averaging 4.0 and $0.4 \mathrm{~g} \mathrm{ha}^{-1}$, respectively (Table 3 ). Consequently, foliar wash-off was not different between wide- and narrow-row soybean (Table 3).

Relative to the calculated mass of metolachlor intercepted by the soybean canopy, the susceptibility of metolachlor to wash-off from soybean foliage was reduced by $98 \%$ in both planting systems $1 \mathrm{~d}$ after application. In contrast, for highly water-soluble and/or ionic pesticides, almost $100 \%$ of the mass intercepted by the foliage is vulnerable to foliar wash-off by rainfall $1 \mathrm{~d}$ after application (Caseley and Coupland, 1980; Pick et al., 1984; Cohen and Steinmetz, 1986; Sundaram, 1990; Willis et al., 1992; Reddy et al., 1994; Wauchope et al., 2004; Matocha et al., 2006). Thus, the susceptibility of herbicide foliar wash-off by rainfall and subsequent loss in surface runoff appears to be lower for non-polar than polar pesticides.

Under the conditions of the field experiment, it was not possible to elucidate the mechanism(s) responsible for the $98 \%$ decline in herbicide mass available for wash-off. We propose that

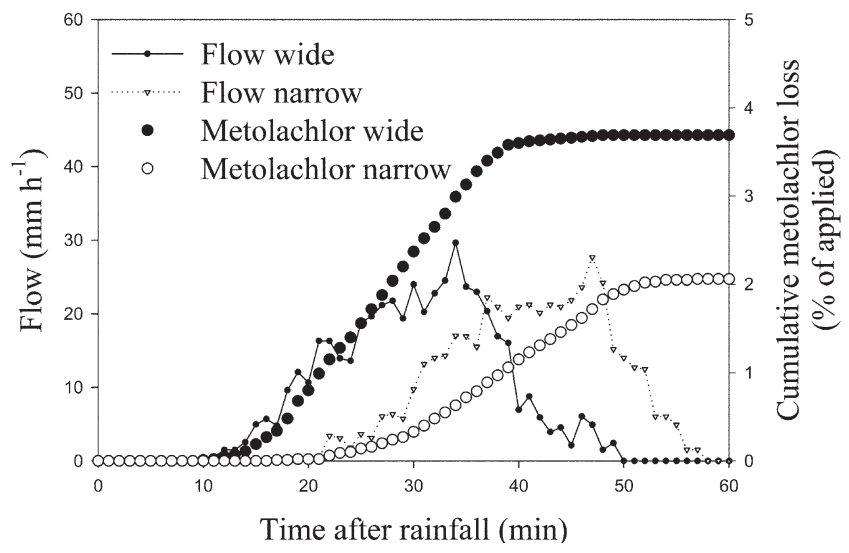

Fig. 1. Hydrograph and cumulative loss of metolachlor as percent applied, $1.2 \mathrm{~kg} \mathrm{ha}^{-1}$ for narrow-row soybean and $1.3 \mathrm{~kg} \mathrm{ha}^{-1}$ for wide-row soybean. Symbols represent the mean of six replicates. 
the primary mechanism(s) responsible for this decline include foliar absorption and/or volatilization. Leonard (1990) suggested that lipophilic compounds, such as metolachlor, penetrate waxes at the leaf surface and become difficult to dislodge by rainfall. This was demonstrated for the lipophilic pesticide toxaphene in which only 7 to $10 \%$ of the mass applied to cotton foliage was available for rainfall wash-off, regardless of time after application (McDowell et al., 1985). Additionally, field studies indicate that metolachlor volatilization ranges from 12 to $47 \%$ of the mass applied and, depending on a number of factors including solar radiation, relative humidity, and soil moisture, most of the volatile loss occurs by $72 \mathrm{~h}$ after application (Keller and Weber, 1997; Prueger et al., 1999; Rice et al., 2002; Prueger et al., 2005). Data also indicate that metolachlor volatilization from plant residues is likely greater than that from soil. For example, Parochetti (1978) reported $0.1 \%$ metolachlor volatization from soil application compared to 12 to $37 \%$ when applied to various plant residues. Regardless of the mechanism(s) responsible for the rapid decline in the mass of metolachlor intercepted by the soybean canopy, our data indicate that the contribution of foliar wash-off to the off-site transport of metolachlor in runoff is negligible for both wide- and narrow-row soybean.

\section{Foliar Wash-off, Absorption, and Translocation}

A laboratory foliar wash-off, absorption, and translocation study was conducted with ${ }^{14} \mathrm{C}$-metolachlor to determine the fate of the herbicide once intercepted by the soybean canopy. Recovery of ${ }^{14} \mathrm{C}$-metolachlor pooled across all treatments was $83 \%$. The percentage of ${ }^{14} \mathrm{C}$-metolachlor in this study that was not recovered (17\%) was within the range of values reported for volatilization loss when applied to soil and foliage (Parochetti, 1978; Keller and Weber, 1997; Prueger et al., 1999; Rice et al., 2002; Prueger et al., 2005). Foliar wash-off of metolachlor applied to the adaxial surface of the terminal soybean leaflet was described by first-order kinetics (Fig. 4). The rapid decline in ${ }^{14} \mathrm{C}$ metolachlor available for wash-off at 8 and $24 \mathrm{~h}$ after application (6 and 4\%, respectively) supports the field wash-off results. Moreover, the laboratory study indicates that as soon as

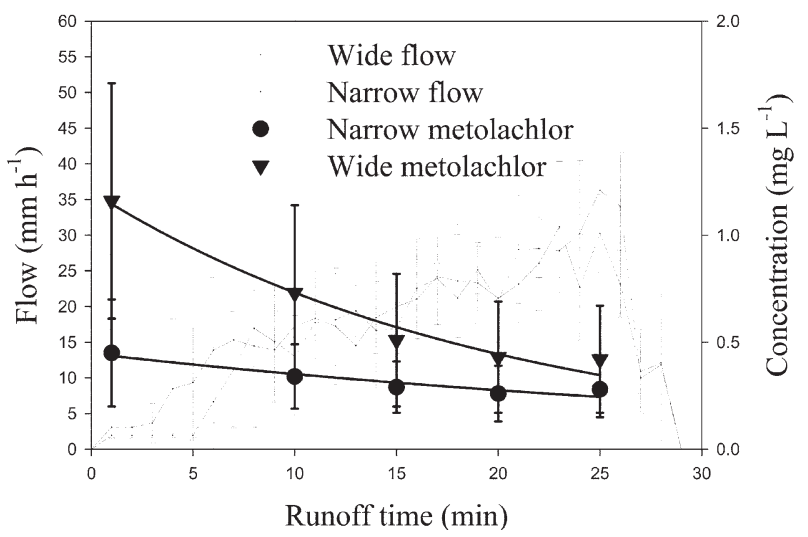

Fig. 2. Hydrograph and chemograph for narrow- and wide-row soybean. Symbols represent the mean of six replicates. Error bars are \pm 1 standard deviation from the mean. First-order kinetics model for narrow-row soybean: $y=0.45 \mathrm{e}^{-0.02 x}, r^{2}=0.90$. First-order kinetics model for wide-row soybean: $y=1.20 \mathrm{e}^{-0.05 x}, r^{2}=0.98$.

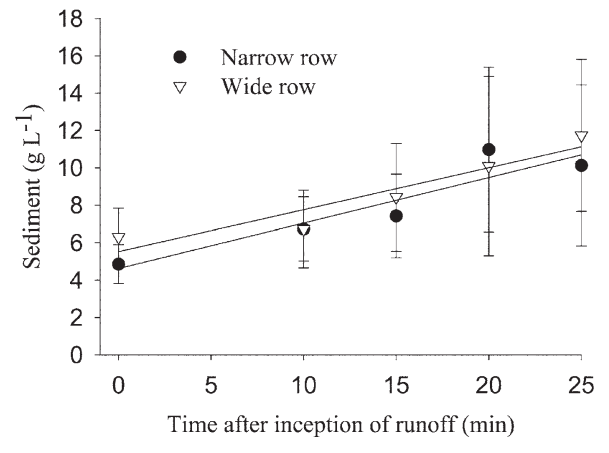

Fig. 3. Sediment concentration in runoff from narrow- and wide-row soybean as a function of time after inception of runoff. Symbols represent the mean of six replicates. Error bars are \pm 1 standard deviation from the mean. Zero-order kinetics model for narrowrow soybean: $y=4.62+0.24 x, r^{2}=0.82$. Zero-order kinetics model for wide-row soybean: $y=5.52+0.22 x, r^{2}=0.85$.

$8 \mathrm{~h}$ after application the potential for foliar wash-off and subsequent transport of metolachlor in surface runoff is negligible.

Absorption of metolachlor applied to the adaxial surface of the terminal leaflet of four-leaf soybean was described by firstorder kinetics (Fig. 5). Absorption was rapid accounting for 94 and $96 \%$ of the recovered ${ }^{14} \mathrm{C}$ at 8 and $24 \mathrm{~h}$, respectively. Twenty-four $\mathrm{h}$ after application, translocation was minimal accounting for less than $0.1 \%$ of the recovered ${ }^{14} \mathrm{C}$ (Fig. 5). Thus, results from this study indicate that at approximately $24 \mathrm{~h}$ after application, $96 \%$ of non-volatilized metolachlor is sequestered in the soybean foliage, primarily at the point of droplet contact. Moreover, these data support the hypothesis that non-polar pesticides penetrate waxes at the leaf surface and become difficult to dislodge by rainfall (McDowell et al., 1985).

\section{Metolachlor Transport in Runoff}

In both wide- and narrow-row systems, the decline in herbicide concentration during the course of the runoff event was described by first-order kinetics (Fig. 2). Regression analysis indicated a higher concentration of metolachlor in runoff from wide-row plots.

Table 3. Calculated mass of metolachlor intercepted by soybean canopy, metolachlor mass available for wash-off $24 \mathrm{~h}$ after application, metolachlor available for wash-off following simulated rainfall event, and percent wash-off of metolachlor in wide- and narrow-row soybeans.

\begin{tabular}{|c|c|c|c|c|}
\hline Treatment & $\begin{array}{c}\text { Mass } \\
\text { intercepted } \dagger\end{array}$ & Pre-rainfall‡ & Post-rainfall§ & Wash-offn \\
\hline & $\mathrm{kg} \mathrm{ha}^{-1}$ & 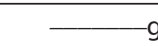 & $\mathrm{ha}^{-1}$ & $\%$ \\
\hline Narrow-row & $0.39 \#(0.13)+\dagger$ & $4.0(1.6)$ & $0.4(0.2)$ & $88(9)$ \\
\hline Wide-row & $0.23(0.04)$ & $3.9(1.3)$ & $0.3(0.1)$ & $92(6)$ \\
\hline$P$ value & 0.0318 & 0.9088 & 0.1463 & 0.1703 \\
\hline
\end{tabular}

† Mass intercepted = canopy coverage at time of herbicide application (fraction) $\times$ herbicide mass applied $\left(\mathrm{kg} \mathrm{ha}^{-1}\right)$.

\# Pre-rainfall herbicide concentration $=$ water-extractable herbicide $24 \mathrm{~h}$ after herbicide application ( g plant $^{-1}$ ) $\times$ plant density (plants ha ${ }^{-1}$ ).

$\S$ Post-rainfall $=$ water-extractable herbicide immediately following simulated rainfall event $\left(\right.$ g plant $\left.^{-1}\right) \times$ plant density $\left(\right.$ plants ha $\left.{ }^{-1}\right)$.

१ Wash-off $=\left[\left(\right.\right.$ Pre-rainfall $\left(\mathrm{g} \mathrm{ha}^{-1}\right)-$ Post-rainfall $\left.\left(\mathrm{g} \mathrm{ha}^{-1}\right)\right) /$ Pre-rainfall $(\mathrm{g}$ $\left.\left.\mathrm{ha}^{-1}\right)\right] \times 100$.

\# Value is the mean of six replicates.

t† Value in parenthesis indicates one standard deviation. 


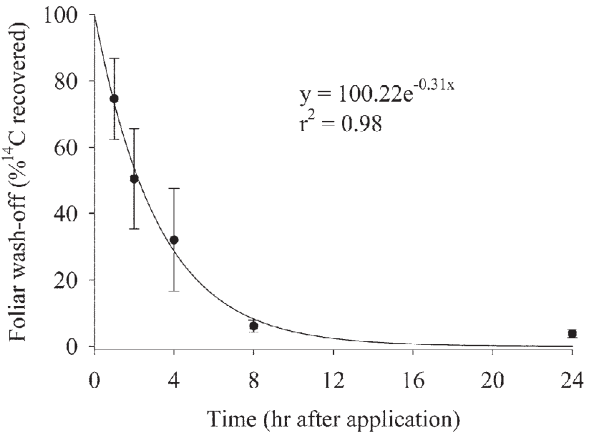

Fig. 4. Foliar wash-off potential of ${ }^{14} \mathrm{C}$-metolachlor applied to the adaxial surface of the last fully expanded terminal leaflet of fourleaf soybean. Symbols represent the mean of six replicates. Error bars are \pm 1 standard deviation of the mean. Data are expressed as percent ${ }^{14} \mathrm{C}$ recovered.

Although runoff rate and cumulative runoff were not different between row spacing (Table 2, Fig. 2), the cumulative loss of metolachlor in surface runoff was 2.1-fold greater in the wide-row system (Table 2). Since cumulative water loss was not different between narrow- and wide-row systems, a greater loss of metolachlor in the wide-row system was due to a higher concentration in runoff.

The concentration of metolachlor in runoff samples was negatively correlated with time to runoff (Fig. 6), similar to results by others (e.g., Leonard, 1990). Since the concentration of an herbicide in surface runoff is strongly correlated to the herbicide mass in the mixing zone (Leonard et al., 1979), data indicate a lower herbicide concentration in the mixing zone of narrowrow soybean. There are two plausible explanations for a lower concentration of metolachlor in the mixing zone of narrow-row soybean. First, more soil was exposed in the wide-row system than the narrow-row system due to lower canopy coverage with approximately $32 \%$ more metolachlor reaching the mixing zone in the former, i.e., $1.07 \mathrm{~kg} \mathrm{ha}^{-1}$ metolachlor for wide-row soybean compared to $0.81 \mathrm{~kg} \mathrm{ha}^{-1}$ metolachlor for narrow-row soybean. Second, due to lower antecedent soil moisture, approximately 9 $\mathrm{mm}$ more water infiltrated in the narrow-row system before inception of runoff. Greater infiltration in the narrow-row-system before inception of surface runoff likely resulted in more herbicide leaching below the mixing zone.

In other reports, runoff losses of metolachlor in soybean when

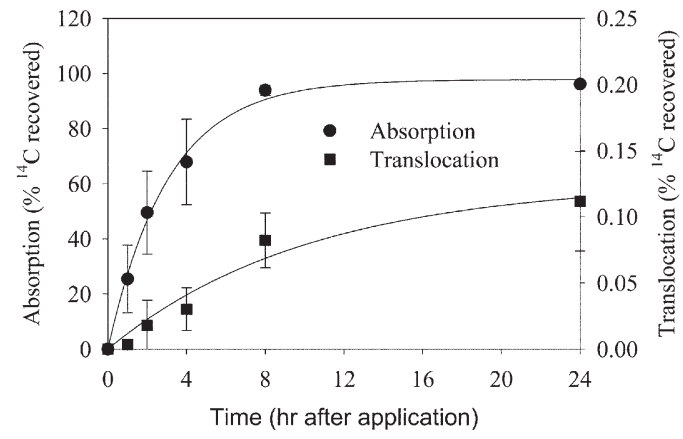

Fig. 5. Absorption and translocation of ${ }^{14} \mathrm{C}$-metolachlor applied to the adaxial surface of the last fully expanded terminal leaflet of fourleaf soybean. Symbols represent the mean of six replicates. Error bars are \pm 1 standard deviation of the mean. Data for absorption and translocation are expressed as percent ${ }^{14} \mathrm{C}$ recovered.

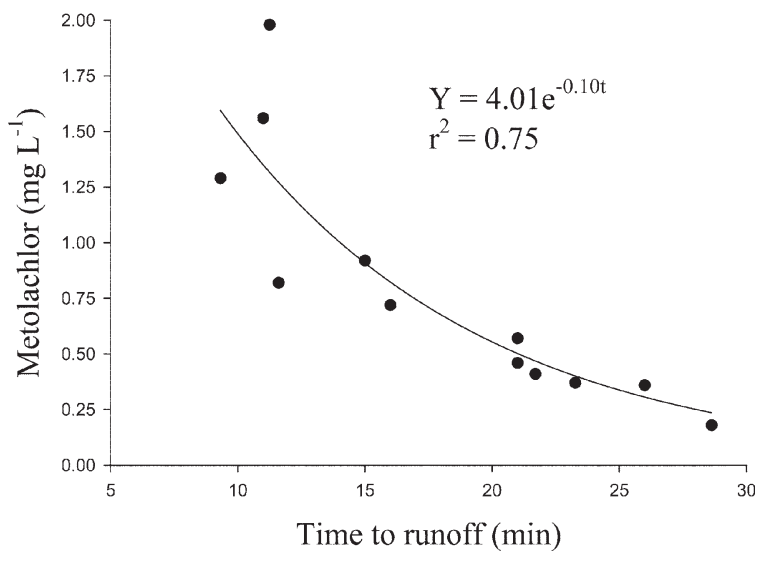

Fig. 6. Relationship between herbicide concentration in the first liter of runoff and time to inception of runoff. Symbols are individual replicates from both wide- and narrow-row soybean.

the herbicide was applied directly to soil before plant emergence averaged 3.1\% and ranged from 0.1 to $21.7 \%$ (Logan et al., 1994; Webster and Shaw, 1996a, 1996b; Southwick et al., 1997; Tingle et al., 1998; Kim and Feagley, 2002). Similar results were observed in the present study where metolachlor was applied after crop emergence. Thus, our data do not indicate that the foliar application of metolachlor to soybean increases its runoff potential relative to a standard pre-emergent herbicide program; however, the mass of metolachlor available for herbicide transport might be reduced in a post-emergence, over the top application program compared to a standard pre-emergent weed control program. Essentially, the mass of metolachlor applied over the top of soybean is reduced in proportion to the canopy coverage at the time of application. Since the runoff potential for an herbicide is proportional to the mass applied (Leonard 1990), the runoff potential of metolachlor applied over the top of soybean is likely reduced relative to a standard pre-emergent application.

\section{Conclusions}

Cumulative metolachlor losses in surface runoff were 2.1-fold greater in wide-row soybean than narrow-row soybean. Two characteristics of narrow-row soybean that reduced metolachlor transport in surface runoff include greater canopy coverage and lower antecedent soil moisture. Canopy coverage and metolachlor mass intercepted by the soybean canopy was 1.7 -fold greater in narrow-row soybean. Foliar absorption and subsequent sequestration of metolachlor by soybean foliage was rapid, with less than $2 \%$ available for foliar wash-off by rainfall $1 \mathrm{~d}$ after application. Consequently, the metolachlor mass reaching the soil surface and available for transport in surface runoff was reduced by $32 \%$ in the narrow-row system. Moreover, lower antecedent soil moisture levels in narrow-row soybean delayed the inception of runoff, increased infiltration, and likely promoted the leaching of metolachlor below the mixing zone. These combined effects reduced the metolachlor mass available for transport in the mixing, thereby curtailing herbicide transport in surface runoff. Results from this study demonstrate potential for narrow-row soybean systems to reduce surface runoff losses of metolachlor applied over the top of the canopy. Yet, future studies are required including (i) effect 
of row spacing on the transport of ionic and non-ionic pesticides applied pre- and post-emergent in other row crops, i.e., corn, cotton, and wheat; and (ii) combined effects of row spacing, planting density, and reduced tillage practices on pesticide transport.

\section{Acknowledgments}

Mention of trade names or commercial products in this publication is solely for the purpose of providing specific information and does not imply recommendation or endorsement by the USDA.

\section{References}

Ahuja, L.R. 1986. Characterization and modeling of chemical transfer to runoff. Adv. Soil Sci. 4:149-188.

Beverlein, D.C., and A.S. Donigian, Jr. 1979. Effectiveness of soil and water conservation practices for pollution control. p. 385-473. In USEPA, EPA-600/3-74-106. U.S. Gov. Print. Office, Washington, DC.

Caseley, J.C., and D. Coupland. 1980. Effects of simulated rain on retention, distribution, uptake, movement, and activity of difenzoquat applied to Avena fatua. Ann. Appl. Biol. 96:111-118.

Cohen, M.L., and W.D. Steinmetz. 1986. Foliar wash-off of pesticides by rainfall. Environ. Sci. Technol. 20:521-523.

Dalley, C.D., M.L. Bernards, and J.J. Kells. 2006. Effect of weed removal timing and row spacing on soil moisture in corn (Zea mays). Weed Technol. 20:399-409.

Hackett, A.G., D.I. Gustafson, S.J. Morgan, P. Hendley, I.V. Wesenbeeck, N.D. Simmons, A.J. Klein, J.M. Kronenberg, J.D. Fuhrman, J.L. Honegger, J. Hanzas, D. Healy, and C.T. Stone. 2005. The acetochlor registration partnership surface water monitoring program for four corn herbicides. J. Environ. Qual. 34:877-889.

Kalkhoff, S.J., K.E. Lee, S.D. Porter, P.J. Terrio, and E.M. Thurman. 2003. Herbicides and herbicide degradation products in Upper Midwest agricultural streams during August base-flow conditions. J. Environ. Qual. 32:1025-1035.

Keller, K.E., and J.B. Weber. 1997. Soybean (Glycine max) influences metolachlor mobility in soil. Weed Sci. 45:833-841.

Kim, J.H., and S.E. Feagley. 2002. Runoff of Trifluralin, metolachlor, and metribuzin from a clay loam soil of Louisiana. J. Environ. Sci. Health B 37:405-415.

Leonard, R.A. 1990. Movement of pesticides into surface waters. p. 303-350. In H.H. Cheng (ed.) Pesticides in the soil environment: Process, impacts, and modeling. SSSA Book Ser. 2. SSSA, Madison, WI.

Leonard, R.A., G.W. Langdale, and W.G. Fleming. 1979. Herbicide runoff from upland piedmont watersheds-data and implications for modeling pesticide transport. J. Environ. Qual. 8:223-229.

Lerch, R.N., and P.E. Blanchard. 2003. Watershed vulnerability to herbicide transport in northern Missouri and southern Iowa streams. Environ. Sci. Technol. 37:5518-5527.

Logan, T.J., D.J. Eckert, and D.G. Beak. 1994. Tillage, crop, and climatic effects on runoff and tile drainage losses of nitrate and four herbicides. Soil Tillage Res. 30:75-103.

Matocha, M.A., L.J. Krutz, K.R. Reddy, S.A. Senseman, M.A. Locke, R.W Steinriede, Jr., and E.W. Palmer. 2006. Foliar wash-off potential and simulated surface runoff losses of trifloxysulfuron in cotton. J. Agric. Food Chem. 54:5498-5502.

McDowell, L.L., G.H. Willis, S. Smith, and L.M. Southwick. 1985. Insecticide wash-off from cotton plants as a function of time between application and rainfall. Trans. ASAE 28:1896-1900.

Parochetti, J.V. 1978. Photodecomposition, volatility, and leaching of atrazine, simazine, alachlor, and metolachlor from soil and plant material. WSSA Abstr. No. 17. Weed Sci. Soc. of Am., Urbana, IL.

Pick, F.E., L.P. van Dyk, and P.R. de Beer. 1984. The effect of simulated rain on deposits of some cotton pesticides. Pestic. Sci. 15:616-623.

Potter, T.L., C.C. Truman, D.D. Bosch, and C.W. Bednarz. 2003. Cotton defoliant runoff as a function of active ingredient and tillage. J Environ. Qual. 32:2180-2188.

Prueger, J.H., T.J. Gish, L.L. McConnell, L.G. Mckee, J.L. Hatfield, and W.P. Kustas. 2005. Solar radiation, relative humidity, and soil water effects on metolachlor volatilization. Environ. Sci. Technol. 39:5219-5226.

Prueger, J.H., J.L. Hatfield, and T.J. Sauer. 1999. Field-scale metolachlor volatilization flux estimates from broadcast and banded application methods in Central Iowa. J. Environ. Qual. 28:75-81.

Purcell, L.C. 2000. Soybean canopy coverage and light interception measurements using digital imagery. Crop Sci. 40:834-837.

Rebich, R.A., R.H. Coupe, and E.M. Thurman. 2004. Herbicide concentrations in the Mississippi River Basin-The importance of chloroacetanilide herbicide degradates. Sci. Total Environ. 321:189-199.

Reddy, K.N., M.A. Locke, and C.T. Bryson. 1994. Foliar washoff and runoff losses of lactofe, norflurazone, and fluometuron under simulated rainfall. J. Agric. Food Chem. 42:2338-2343.

Rice, P.C., C.B. Nochetto, and P. Zara. 2002. Volatilization of Trifluralin, atrazine, metolachlor, chlorpyrifos, $\alpha$-endosulfa, and $\beta$-endosulfan from freshly tilled soil. J. Agric. Food Chem. 50:4009-4017.

SAS Institute. 2004. SAS version 9.1. SAS Institute Inc., Cary, NC.

Scribner, E.A., W.A. Battaglin, D.A. Goolsby, and E.M. Thurman. 2000. Changes in herbicide concentrations in midwestern streams in relation to changes in use, 1989-1998. Sci. Total Environ. 248:255-263.

Sharrat, B.S., and D.A. McWilliams. 2005. Microclimatic and rooting characteristics of narrow-row versus conventional-row corn. Agron. J. 97:1129-1135.

Shelton, D.P., P.J. Jasa, and E.C. Dickey. 1986. Soil erosion from tillage and planting systems used in soybean residue: Part I-Influences of row spacing. Trans. ASAE 29:756-760.

Smith, S.K., T.G. Franti, and S.D. Comfort. 2002. Impact of initial soil water content, crop residue cover, and post-herbicide irrigation on herbicide runoff. Trans. ASAE 45:1817-1824.

Southwick, L.M., G.H. Willis, O.A. Mercado, and R.L. Bengtson. 1997. Effects of subsurface drains on runoff losses of metolachlor and Trifluralin from Mississippi River alluvial soil. Arch. Environ. Contam. Toxicol. 32:106-109.

Sundaram, A. 1990. Effects of adjuvants on glyphosate wash-off from white birch foliage by simulated rainfall. J. Environ. Sci. Health B 2:37-67.

Tingle, C.H., D.R. Shaw, M. Boyette, and G.P. Murphy. 1998. Metolachlor and metribuzin losses in runoff as affected by width of vegetative filter strips. Weed Sci. 46:475-479.

Truman, C.C., and R.G. Williams. 2001. Effects of peanut cropping practices and canopy cover conditions on runoff and sediment yield. J. Soil Water Conserv. 56:152-159.

Wauchope, R.D. 1987a. Tilted-bed simulation of erosion and chemical runoff from agricultural fields: I. Runoff of sediment and sedimentassociated copper and zinc. J. Environ. Qual. 16:206-212.

Wauchope, R.D. 1987b. Tilted-bed simulation of erosion and chemical runoff from agricultural fields: II. Effects of formulation on atrazine runoff. J. Environ. Qual. 16:212-216.

Wauchope, R.D., W.C. Johnson, III, and H.R. Sumner. 2004. Foliar and soil deposition of pesticide sprays in peanuts and their wash-off and runoff under simulated worst-case rainfall conditions. J. Agric. Food Chem. 52:7056-7063.

Webster, E.P., and D.R. Shaw. 1996a. Impact of vegetative filter strips on herbicide loss in runoff from soybean (Glycine max). Weed Sci. 44:662-671.

Webster, E.P., and D.R. Shaw. 1996b. Off-site runoff losses of metolachlor and metribuzin applied to differing soybean (Glycine max) production systems. Weed Technol. 10:556-564.

Willis, G.H., L.L. McDowell, L.M. Southwick, and S. Smith. 1992. Wash-off of ultralow-volume-oil-applied insecticides from plants as a function of time between application and rainfall. J. Environ. Qual. 21:373-377.

Zablotowicz, R.M., M.A. Locke, L.J. Krutz, R.N. Lerch, R.E. Lizotte, S.S. Knight, R.E. Gordon, and R.W. Steinriede. 2006. Influence of watershed system management on herbicide concentrations in Mississippi Delta oxbow lakes. Sci. Total Environ. 370:552-560.

Zhang, X.C., L.D. Norton, and M. Hickman. 1997. Rain pattern and soil moisture content effects on atrazine and metolachlor losses in runoff. J. Environ. Qual. 26:1539-1547. 